\title{
EFFECT OF EXTRACTION SYSTEM AND REFINING ON THE STEROL COMPOSITION OF POMACE-OLIVE OILS
}

\author{
Kamel ESSID ${ }^{1 *}$, Mahmoud TRABELSI ${ }^{1}$, Mohamed Hédi FRIKHA ${ }^{1}$ \\ ${ }^{1}$ Laboratory of applied chemistry: Heterocycles, Fats and Polymers
}

Faculté des sciences de Sfax, Route de Soukra Km 3,5-BP 1171-3000. Sfax. Tunisia

*Corresponding author: kamelessid.issat@yahoo.fr

\begin{abstract}
Research has been carried out to ascertain the effects of refining and different processing systems on the sterol compositions of pomace-olive oils and especially on the $\Delta$-7-stigmastenol. The International Olive Council imposes limits or ranges for each type of sterol based on the natural levels found in traditional olive oil varieties. The required sterol profile (as $\%$ of total sterols) is for the $\Delta$-7-stigmastenol $\leq 0.5 \%$. A high content of this compound is non-in compliance with the International Olive Oil Standards and is at the origin of major problems at the level of the exportation because it gives the impression of the presence of seed oil in this olive oil.

The sterol composition of the refined pomace-olive oils is non-in conformity with these international standards, because the percentage of $\Delta$-7-stigmastenol exceeds slightly the tolerated limits. This percentage is more important mainly when extraction of oil is with the continuous chain. In refining, the neutralization step is with soda. The content of this compound remain invariable after neutralization by lime.
\end{abstract}

\section{Indexing terms/Keywords:}

Refining; extraction; pomace-olive oil; sterol; lime.

\section{Council for Innovative Research}

Peer Review Research Publishing System

Journal: Journal of Advances in Chemistry

Vol. 10, No. 3

editorjaconline@gmail.com

www.cirjac.com 


\section{INTRODUCTION}

The sterol composition constitutes the fingerprint of a vegetable oil [1]. Extraction of oil and refining can occur to modifications in the sterolic composition. Olive oil differently from most vegetable oils can be consumed without further treatments. However, a refining process is necessary for making edible lampante olive oils. Refining process subjects vegetable oils to high Temperatures, alkali and acid mediums, resulting from bleaching earths and sodium hydroxide, and to metal processing equipments. In addition, soda used in the neutralization step eliminates some of the principal components responsible for oxidative stability, such as tocopherols [2], and can involve losses of sterols, which constitute $30-60 \%$ of the unsaponifiables. Total sterol losses can be as much as $15 \%$. Pomace olive-oils are generally refined to yield an odorless, bland, and oxidatively stable edible oils. Each processing step has specific functions to remove undesirable components [3-5]. However, certain minor constituents have to be removed with possible loss of desirable materials. A variation in the content of one compound in the sterol composition is non-in compliance with the International Olive Oil Standards and is at the origin some problems because it gives the impression of the presence of other vegetable oil in this olive oil. Several studies have been conducted to determine the factors affecting the quality of olive oil, particularly the sterol profile. Considering that $\beta$-sitosterol is the most abundant sterol in the majority of oils, its value has only limited use for the authenticity assessment and differentiation of vegetable oils [6,7]. Olive oil adulterated with soybean, grapeseed or sunflower oil can be detected on the basis of the concentrations of campesterol and stigmasterol. However, an addition of low amounts of these oils to olive oil cannot be detected with these markers because of their natural presence in olive oil. Sunflower oil is characterized by high concentrations of $\Delta$-7-sterols (up to $37 \% \mathrm{w} / \mathrm{w}$ of the total desmethylsterols). The limit set in the EU for the marker substance $\Delta$-7-stigmastenol is at $0.5 \%$ in olive oil [8]. The effect of factors on the $\Delta$-7-stigmastenol level in olive oil has not been investigated in great depth because it has only been recently designated as a criterion for olive oil quality by the International Olive Oil Council. Therefore, there is a need to investigate the factors that affect $\Delta-7$-stigmastenol levels in olive oil and how these factors can be optimized to solve this problem. In a previous work we have describe a new technique to neutralize olive oils with very high acidities (10-30\%) using lime in a slightly-hydrated liquid-solid medium [9]. Virgin olive oils were obtained from the fruit expression process of olive fruits. However, lamp olive oils (acidity $>3.3 \%$ ) and olive residue oils presenting high acidities (8-10\%) are considered as naturally degraded oils and must be refined before any use as edible oils. The aim of this work is to evaluate the total composition of sterols in refined pomace olive oils, neutralized with soda or lime in a slightly hydrated medium and in olive oils obtained with different extraction technologies. This part of the study was focused especially on the content of $\Delta$-7-Stigmastenol. Another objective was to evaluate the effect of refining and the type of extraction on the oil oxidative stability. In olive oil, there is a series of compounds with asserted antioxidant power, such as polyphenols and tocopherols.

\section{EXPERIMENTAL}

\section{Materials and methods}

\subsection{Neutralization with soda or lime}

Oil $(20 \mathrm{~g})$ and the necessary amount plus 10\% excess of neutralizing agent [sodium hydroxide or lime containing $69 \%$ $\mathrm{Ca}(\mathrm{OH})_{2}$, calculated from the acidity of the oil sample, were charged into an open reactor maintained at ambient temperature. The reaction mixture was subjected to agitation with a magnetic stirrer, then slightly hydrated $(0.5 \mathrm{~g}$ of distilled water) to ensure ionization of the alkaline agent.

\section{Materials}

The olive oils used for experiments were obtained from Sios-Zitex refinery in Sfax (Tunisia). All chemicals used were of analytical grade.

\section{Analytical procedure}

\subsection{Determination of Current Indexes}

To characterize the oils used in this work, we carried out the following analyses: The peroxide index was carried out according to $\mathrm{COI}$ official methods [10]. The Titratable acidity was based on a volumetric titration of the free acidity by a 7.1 $\mathrm{g} / \mathrm{L}$ aqueous solution of sodium hydroxide [11]. The conjugated diene level of neutralized and bleached oils was determined by a UV spectrophotometric method with the aim of deducing their respective oxidative state [12].

\subsection{Determination of tocopherol composition by HPLC}

The normal phase-HPLC (NP-HPLC) procedure was based on AOCS Official Method Ce 8-89. The sample was dissolved in hexane and injected into a NP silica-based column (Alltima Silica $5 \mathrm{U}, 250 \mathrm{~mm} \times 4.6 \mathrm{~mm}$ i.d.; particle size: $5 \mu \mathrm{m}$; Alltech, Lokeran, Belgium) [13]. The mobile phase consisted of hexane to which a small amount of isopropanol was added, and its flow rate was $1.2 \mathrm{~mL} / \mathrm{min}$ (= 32 bar column pressure). The chromatograph was a Hewlett-Packard (series 1050; Palo Alto, $\mathrm{CA})$, equipped with a UV detector set at $292 \mathrm{~nm}$ and a sample loop of $10 \mu \mathrm{L}$.

\subsection{Determination of sterol composition by GC}

Oils were analyzed by using a Shimadzu 14 B gas chromatograph (Kyoto, Japan) under the following conditions [14]: 25 $\mathrm{m}$ length capillary tube; $0.25 \mathrm{~mm}$ column i.d., $0.25 \mathrm{~mm}$ film thickness; Permabond SE 54 (Macherey-Nagel, Düren, 
Germany) fixed phase; $300^{\circ} \mathrm{C}$ injector temperature; $265^{\circ} \mathrm{C}$ column temperature; and helium carrier gas. The sterols were identified by comparison with the sterols of the reference oil analyzed under the same conditions.

\subsection{Oxidative stability}

A Metrohm (Herisau, Switzerland) Rancimat model 679 was used to measure the oxidative stabilityof oils [15]. Five grams of oil was introduced into each reaction tube, and the temperature was fixed at $100^{\circ} \mathrm{C}$ with an air flow regulated to $20 \mathrm{~L} / \mathrm{h}$ for $48 \mathrm{~h}$.

\section{RESULTS AND DISCUSSIONS}

\section{Effect of the mode of extraction on the quality of olive-pomace oils}

\subsection{Preliminary analysis of pomace-olive oils extracted cold and hot}

The pomace-olive oil extracted hot (table 1) presents acidity and a coefficient of specific extinction (K270) superior to those of the oil extracted cold. The increase of the coefficient K270 is associated to the temperature which favors the formation of the secondary products of oxidation. The conjugated trienes and the secondary products of oxidation, $\alpha$ unsaturated aldehydes and ketones, absorb at $270 \mathrm{~nm}$. The determination of the absorbances at $270 \mathrm{~nm}$ allowed the detection and the evaluation of the oxidation products. In the case of the pomace-olive oil extracted hot, the decrease in the peroxide indexes was accompanied by an increase in the absorbance at $270 \mathrm{~nm}$ which can be explained by transformation of a part of the hydroperoxides into secondary products of oxidation (aldehydes and ketones). The contribution of conjugated trienes, suitable to be formed during the extraction, whose absorbance, at $270 \mathrm{~nm}$, was not probable because the content of the trienic acid (linolenic) was very low in the olive oil (approximately $0.6 \%$ ). So these reactions of oxidation which transform peroxides and hydroperoxides into aldehydes and ketones $\alpha, \beta$-unsaturated [16].

The hot extraction of oil requires an increase of the temperature which also favors the reaction of hydrolysis and the liberation of free fatty acids with as consequence an increase of the acidity of the oil.

The peroxide index $(\mathrm{PI})$ values confirmed these remarks and showed an increase in the quantity of active oxygen in the two extracted samples, when compared to the reference oil sample. This increase was more significant in the case of the oil extracted cold. However, these values remained low and did not affect the quality of the extracted oils, since they were in conformity with the international standard adopted for olive-residue oils [17]. It appears in the light of these preliminary analyses that the principal physicochemical characteristics of oils were slightly modified after extraction. These modifications were less important with the cold extraction.

\subsection{Oxidative stability of pomace-olive oils extracted cold and hot}

Tocopherols and polyphenols present a vitamin capacity and play the role of natural antioxidants. The amounts of these compounds in olive-residue oils extracted hot and cold (table 2) showed a reduction after extraction. This reduction, determined in percentage of losses was more significant during the hot extraction [18]. Thus the quantity of tocopherols and polyphenols swept along was more important. The losses were less significant in the case of the pomace-olive oil extracted cold.

Oil is more resistant to oxidation and consequently more stable since the time for decomposition is larger. The results of Table 2 showed a strong reduction in times of oxidation resistance of the two extracted oils compared to the reference oil. This reduction was much more significant when oils were extracted hot. The pomace-olive oil extracted hot, having lost more tocopherols and polyphenols, was less resistant to oxidation than that extracted cold.

It appears in the light of all the physicochemical analyses that the cold extraction was better adapted to the extraction of pomace-olive oils. It can preserve the composition of the minor part, in particular the antioxidants. The fundamental cause of the quality loss of pomace-olive oil extracted hot lives in the operation of heating of the oil with high temperatures which makes fast the process of degradation, so provoking a fast acidification together with phenomena of oxidation of the oil and degradation of plant tissues and some compounds susceptible to be extracted with the oil. All this exceeds the impurities and make difficult the continuation of the operation of refining. However, the biological value of a vegetable oil is related mainly to its minor components and more particularly to the sterol fraction which deserves a detailed attention.

\subsection{Sterol Composition}

The sterol composition is summarized in Table 3. The $\beta$-sitosterol was the most abundant sterol of the sterolic fraction in all the samples, followed-up of exceeds $\Delta$-5-avenasterol and campesterol. The sterol compositions of both studied samples of pomace-olive oil extracted cold and hot are very near to that of the virgin olive oil taken as reference. The International Olive Oil Standards require a sum of percentages of B-sitosterol, $\Delta-5$-Avénastérol, Clerosterol, Sitostanol and of $\Delta$-5-24-Stigmastadiénol superior to $93 \%$, without that the percentage of campesterol exceeds $4 \%$ and that of $\Delta-7$ Stigmastenol exceeds $0.5 \%$. This last sterol is a minority in olive oil. An increase of the content of the $\Delta$-7-Stigmastenol compound was noted in the case of pomace-olive oil extracted hot. The contents of this compound remained inferior to the limit required by the standards after a cold extraction. The increase in the content of $\Delta$-7-Stigmastenol in the pomace-olive oil extracted hot is probably due to the various stages of the extraction process in a high temperature. We focus on the comportment of oil at temperatures varying around the temperature of the hot extraction. 


\section{Effect of heating on the Sterol composition of pomace-olive oil extracted hot}

The sterol compositions in all the analyzed samples (table 4) show that the content of $\Delta$-7-Stigmastenol remain superior to the value $0.5 \%$ fixed by the International Olive Oil Standards.

It is to be announced that the total sterols remain practically constant. The increase in the content of the $\Delta$-7-Stigmastenol was at the same time as the decrease of some other sterols such as the $\beta$-sitosterol, the most abounding sterol.

\section{Sterol composition of pomace-olive oils extracted by continuous or classic chains}

\subsection{Pomac-olive oil extracted on the scale of the laboratory}

The results reported in the table 5 show that the content of the $\Delta$-7-Stigmastenol in pomace-olive oil extracted by the continuous chain is more important than that extracted by the classic chain. The increase of the content of the $\Delta-7$ Stigmastenol is accompanied by a decrease of some sterols mainly the ß-sitosterol. These modifications are probably due to the incorporation of water during the extraction of oil which can favor the solubility of a sterol. Results show that total sterols content of pomace-olive oil extracted by the continuous chain is significantly lower than that of oil extracted with the classic chain. With a continuous chain system, the addition of water during separation of the oil from vegetable water might explain the different results obtained in this study. Low sterol level in oil extracted with continuous chain occurs because water is used to dilute the olive paste before extraction with a centrifugal decanter. In the classic chain system, water is not added to olive paste.

In the continuous chain system, warm water is added during the separation of oil from oily must to obtain cleaner oil. Because of dilution, water lowers the concentration of these sterols and diminishes their concentrations in the oily phase. Being soluble in water a fraction of sterols such as $\beta$-sitosterol lowers their concentration ratios in the oily must and therefore, because of the partition equilibrium law, increases the concentration of some other sterols such as $\Delta-7$ stigmastenol [19]. The increase of $\Delta-7$-stigmastenol percentage in olive oil will not adversely affect the quality of oil. On the contrary, an increase of this sterols has known benefits, it helps preventing absorption of cholesterol from the intestine wall. But this little high content of this compound is non-in compliance with the International Olive Oil Standards and is at the origin of major problems at the level of the exportation because it gives the impression of the presence of seed oil in this olive oil.

\subsection{Pomac-olive oil extracted in the industrial scale}

The conformity of the analyses of the sterol composition in all the samples of oil treated in the industrial scale with the results found on the scale of the laboratory (Table 6). For oil obtained by cutting between both types of extractions, we also notice that the percentage of $\Delta$-7-Stigmastenol remains high and exceeds the limit $0.5 \%$ fixed by the International Olive Oil Standards. This percentage is important mainly in the pomace-olive oil extracted by the classic chains.

\section{Variation of the sterol composition during the stages of refining}

The sterol composition in the samples of oil, corresponding to every stage of refining (table 7 ), shows that the content of $\Delta$ 7 -Stigmastenol remains superior to the value fixed by the Olive Oil Standards $(0.5 \%)$. We note particularly an important increase of the content of this sterol after the neutralization. Then a light increase during the stage of bleaching process developed to remove from the oil the natural pigments, compromised by bad preservation and responsible of unpleasant colorings, metals (iron or cooper) and residual soaps [20]. The percentage in this alcohol remains practically unchangeable during the stage of deodorization the final treatment step in the refining process from crude oil to finished oil. Previous studies showed that under usual refining conditions only a minor decrease in the level of steryl esters has been observed [21,22]. However, by strong refining all sterols including their esters can be removed [23,24].

\section{Sterol compositions of three varieties of pomace-olive oils before and after refining}

The comparison between Tunisian and two foreign (spanich and Portugais) pomace-olive oils before and after refining (table 8), shows a content of $\Delta$-7-Stigmastenol lower than the limit required by the International Olive Oil Standards for both of the foreign varieties and a value slightly superior to the limit in the Tunisian pomace-olive oil. An important increase of the content of $\Delta-7$-Stigmastenol in three varieties is registered after the refining. The Tunisian olive oil exceeds further to this increase the limit required by the International Olive Oil Standards while the two other varieties stay within the limit of the standards.

It appears clearly, according to these results that the high content of $\Delta$-7-stigmastenol in the Tunisian pomace-olive oil is not only due to the process of refining. Topography, olive storage before pressing, geographical area, olive seeds, press temperature, olive leaves, soil type, harvest time, olive variety and olive oil storage seem to play a very important role. In more the varietal and the climatic factors can enter partly this abnormal sterol composition in particular by the fact of an important drought during the maturation of olives in Tunisia.

\section{Sterol composition of pomace-olive oil neutralized by soda or by lime [9]}

As shown in table 9, the sterol composition of the pomace-olive oil sample raw, is non-in conformity with these international standards, because the percentage of the $\Delta-7-$ Stigmastenol exceeds slightly the tolerated limits. The sterol contents of the compounds remain practically invariable after neutralization by the calcium hydroxide. Content of the $\Delta-7-$ 
Stigmastenol in the pomace-olive oil neutralized by soda is definitely higher than that neutralized by the lime.

\section{REFERENCES}

[1] Lanzon, A., Albi, T., Cert, A. and Gracian, J. 1994. The Hydrocarbon Fraction of Virgin Olive Oil and Changes Resulting from Refining. Ibid. 71, 285-291.

[2] Perrin, J.L. 1992. Minor Compounds and Natural Antioxidants of Olive and Its Oil, Rev. Fr. Corps Gras. 39, $25-32$.

[3] Ferrari, R.A., Schulte, W., Esteves, W., Brühl, L. and Mukherjee, K.D. 1996. Minor constituents

of oils during industrial processing. J. Am. Oil Chem. Soc. 73, 587-592.

[4] Jung, M.Y., Yoon, S.H., Min, D.B. 1989. Effects of Processing Steps on the Contents of Minor Compounds and Oxidation of Soybean Oil. J. Am. Oil Chem. Soc. 60, 118-120.

[5] Rabascall, N. H., Riera, J. B. 1987. Variaciones del contenido en tocoferoles y tocotrienoles durante los procesos de obtencione hidrogenacion de aceites comestibles. Grasas Aceites. 38, 145-148.

[6] Cimato, A. 1990. Olive oil maturation. Olivae. 31, 20-22.

[7] Mandl, A., Reich, G., Lindner, W. 1999. Detection of adulteration of pumpkin seed oil by analysis of content and composition of specific phytosterols. Eur. Food Res. Technol. 209, 400-406.

[8] International standard. 2003. Trade standard applying to olive oils and olive pomace oils. COI/T.15, Doc NO. 3.

[9] Essid, K., Trabelsi, M., Frikha, M.H. 2006. Effects of Neutralization with Lime on the Quality of Acid Olive Oil. JAOCS. 83, 10-15.

[10] International standard. 1998. Animal and vegetable fats and oils. Determination of peroxide index. ISO 3960, 3rd ed.

[11] International standard. 1996. Animal and vegetable fats and oils. Determination of acid value and acidity. ISO 660, 2nd ed.

[12] International standard. 1996. COI/T-20, Doc. No. 19.

[13] International Oleicol Council. 1997. Determination of Tocopherols and Tocotrienols in Vegetable Oils and Fats by HPLC, 5th ed.

[14] International standard. 1992. Determination of the Composition and Content of Sterols by Capillary-Column Gas Chromatography; COI/T.20, Doc. NO.10.

[15] AOCS, Oil Stability Index (OSI) 1997. Official Methods and Recommended Practices of the AOCS, 5th edn., AOCS Press, Champaign, Method Cd 12-92.

[16] Fukuzumi, K. 1980. Aging in Relation to Lipids: Lipoperoxide, Essential Fatty Acids, Vitamin E. Oleagineux. 35, 511514.

[17] International Oleicol Council. 1990. Amélioration de la Qualité d'Huile d'Olive; Madrid.

[18] Verleyen, T., Kamal-Eldin, A., Dobarganes, C., Verhé, R., Dewettinck, K.; Huyghebaert, A. 2001. Modeling of aTocopherol Loss and Oxidation Products Formed During Thermoxidation in Triolein and Tripalmitin Mixtures. Lipids. 36, 719-726.

[19] Di Giovacchino, L., Solinas, M., Miccoli, M. 1994. Effect of extraction systems on the quality of virgin olive oil. J.A.O.C.S. 71, 1189-1194.

[20] Antonopoulos, K., Valet, N., Spiratos, D., Siragakis, G. 2006. Olive oil and pomace olive oil processing. Grasasy Aceites. 57, 56-67.

[21] Ferrari, R.A., Esteves, W., Mukherjee, K.D., Schulte, E. 1997. Alteration of sterols and steryl esters in vegetable oils during industrial refining. J. Agric. Food Chem. 45, 4753-4757.

[22] Ferrari, R.A., Schulte, E., Esteves, W., Brühl, L., Mukherjee, K.D. 1996. Minor constituents of vegetable oils during industrial processing. J. Am. Oil Chem. Soc. 73, 587-592.

[23] Grob, K., Giuffré, A.M., Leuzzi, U., Mincione, B. 1994b. Recognition of adulterated oils by direct analysis of the minor components. Fat Sci. Technol. 96, 286-290.

[24] Gordon, M.H., Griffith, R.E. 1992b. Steryl ester analysis as an aid to the identification of oils in blends. Food Chem. 43, 71-78. 
Table 1. Preliminary analysis ${ }^{a}$ of pomace-olive oils extracted cold and hot

\begin{tabular}{llllll}
\hline Analysis & $\begin{array}{l}\text { Reference } \\
\text { VOO }\end{array}$ & $\begin{array}{l}{ }^{\mathrm{D}} \mathrm{POO} \\
\text { extracted } \\
\text { cold }\end{array}$ & $\begin{array}{l}{ }^{\mathrm{D}} \mathrm{POO} \\
\text { extracted } \\
\text { hot }\end{array}$ & $\begin{array}{l}{ }^{\mathrm{C}} \mathrm{POO} \\
\text { extracted } \\
\text { cold }\end{array}$ & $\begin{array}{l}{ }^{\mathrm{C}} \mathrm{POO} \\
\text { extracted } \\
\text { hot }\end{array}$ \\
\hline Acidity (mass \%) & 4.20 & 7.10 & 6.27 & 7.82 \\
\hline K270 & 1.04 & 1.36 & 1.44 & 1.87 \\
\hline $\begin{array}{l}\text { Peroxide value } \\
\text { (milliequivalent/kg) }\end{array}$ & 10.17 & 15.94 & 14.64 & 16.05 & 14.90
\end{tabular}

a Data are means of triplicates.

b First sample of oil

c second sample of oil

Table 2. Oxidative stability ${ }^{a}$ of olive-pomace oils extracted cold and hot

\begin{tabular}{|c|c|c|c|c|c|}
\hline Analysis & $\begin{array}{l}\text { Reference } \\
\text { VOO }\end{array}$ & $\begin{array}{l}{ }^{\mathrm{b}} \mathrm{POO} \\
\text { extract } \\
\text { cold }\end{array}$ & $\begin{array}{l}{ }^{\mathrm{b}} \mathrm{POO} \\
\text { extracted } \\
\text { hot }\end{array}$ & $\begin{array}{l}{ }^{\mathrm{c}} \mathrm{POO} \\
\text { extracted } \\
\text { cold }\end{array}$ & $\begin{array}{l}{ }^{\mathrm{C}} \mathrm{POO} \\
\text { extracted } \\
\text { hot }\end{array}$ \\
\hline $\begin{array}{l}\text { Time of oxidation } \\
\text { (hours) }\end{array}$ & 14.60 & 3.57 & 2.30 & 3.35 & 2.00 \\
\hline $\begin{array}{l}\text { Total Tocopherols } \\
\text { (ppm) }\end{array}$ & 478 & 317 & 158 & 287 & 145 \\
\hline $\begin{array}{l}\text { Loss of Tocopherols } \\
(\%)\end{array}$ & - & 33.68 & 66.94 & 39.95 & 69.66 \\
\hline $\begin{array}{l}\text { Total Polyphenols } \\
\text { (ppm) }\end{array}$ & 182 & 143 & 33 & 120 & 29 \\
\hline $\begin{array}{l}\text { Loss of Polyphenols } \\
(\%)\end{array}$ & - & 21.43 & 81.86 & 34.06 & 84.06 \\
\hline \multicolumn{6}{|l|}{$\begin{array}{l}\text { a Data are means of trip } \\
\text { b First sample of oil } \\
\text { c second sample of oil }\end{array}$} \\
\hline Sterol & $\begin{array}{l}\text { Reference } \\
\text { VOO }\end{array}$ & $\begin{array}{l}{ }^{\mathrm{b}} \mathrm{POO} \\
\text { extract } \\
\text { hot }\end{array}$ & $\begin{array}{l}{ }^{\mathrm{D}} \mathrm{POO} \\
\text { extract } \\
\text { cold }\end{array}$ & $\begin{array}{l}{ }^{\mathrm{C}} \mathrm{POO} \\
\text { extracted } \\
\text { hot }\end{array}$ & $\begin{array}{l}{ }^{\mathrm{C}} \mathrm{POO} \\
\text { extracted } \\
\text { cold }\end{array}$ \\
\hline Cholesterol & $\begin{array}{l}0.13 \\
(0.01)\end{array}$ & $\begin{array}{l}0.32 \\
(0.01)\end{array}$ & $\begin{array}{l}0.16 \\
(0.03)\end{array}$ & $\begin{array}{l}0.21 \\
(0.01)\end{array}$ & $\begin{array}{l}0.23 \\
(0.05)\end{array}$ \\
\hline $\begin{array}{l}\text { 24-methylene- } \\
\text { cholesterol }\end{array}$ & $\begin{array}{l}0.09 \\
(0.01)\end{array}$ & $\begin{array}{l}0.13 \\
(0.02)\end{array}$ & $\begin{array}{l}0.08 \\
(0.01)\end{array}$ & $\begin{array}{l}0.13 \\
(0.01)\end{array}$ & $\begin{array}{l}0.17 \\
(0.01)\end{array}$ \\
\hline Campesterol & $\begin{array}{l}3.46 \\
(0.77)\end{array}$ & $\begin{array}{l}3.35 \\
(0.83)\end{array}$ & $\begin{array}{l}3.27 \\
(1.11)\end{array}$ & $\begin{array}{l}3.27 \\
(0.30)\end{array}$ & $\begin{array}{l}3.29 \\
(0.84)\end{array}$ \\
\hline Campestanol & $\begin{array}{l}0.14 \\
(0.01)\end{array}$ & $\begin{array}{l}0.17 \\
(0.04)\end{array}$ & $\begin{array}{l}0.11 \\
(0.02)\end{array}$ & $\begin{array}{l}0.19 \\
(0.01)\end{array}$ & $\begin{array}{l}0.13 \\
(0.01)\end{array}$ \\
\hline Stigmasterol & $\begin{array}{l}0.91 \\
(0.15)\end{array}$ & $\begin{array}{l}1.12 \\
(0.17)\end{array}$ & $\begin{array}{l}0.69 \\
(0.16)\end{array}$ & $\begin{array}{l}1.19 \\
(0.13)\end{array}$ & $\begin{array}{l}0.69 \\
(0.16)\end{array}$ \\
\hline
\end{tabular}




\begin{tabular}{llllll}
\hline Chlerosterol & 0.79 & 0.94 & 0.71 & 0.97 & 1.00 \\
& $(0.43)$ & $(0.49)$ & $(0.54)$ & $(0.43)$ & $(0.42)$ \\
\hline$\beta$-sitosterol & 85.28 & 84.42 & 86.32 & 85.64 & 86.28 \\
& $(5.55)$ & $(5.55)$ & $(5.60)$ & $(5.40)$ & $(5.43)$ \\
\hline Sitostanol & 0.97 & 1.03 & 0.82 & 0.88 & 0.87 \\
& $(0.11)$ & $(0.02)$ & $(0.02)$ & $(0.02)$ & $(0.08)$ \\
\hline$\Delta$-5-avenasterol & 6.62 & 6.09 & 6.54 & 5.98 & 5.54 \\
& $(0.78)$ & $(0.71)$ & $(0.71)$ & $(0.62)$ & $(0.71)$ \\
\hline$\Delta-5,24-$-stigmastadienol & 0.53 & 0.77 & 0.41 & 0.63 & 0.59 \\
& $(0.04)$ & $(0.02)$ & $(0.02)$ & $(0.02)$ & $(0.07)$ \\
\hline$\Delta-7$-stigmastenol & 0.42 & 0.54 & 0.38 & 0.53 & 0.48 \\
& $(0.08)$ & $(0.08)$ & $(0.08)$ & $(0.07)$ & $(0.08)$ \\
\hline$\Delta$-7- Avenasterol & 0.66 & 0.72 & 0.51 & 0.38 & 0.56 \\
& $(0.16)$ & $(0.15)$ & $(0.14)$ & $(0.14)$ & $(0.10)$ \\
\hline
\end{tabular}

a Data are means of triplicates, and SD (standard deviation) is given in parentheses

b First pomace oil sample

c Second pomace oil sample.

Table 4. Effect of the temperature variation on the Sterol composition ${ }^{a}$ of pomace-olive oil extracted hot

\begin{tabular}{|c|c|c|c|c|c|}
\hline & \multicolumn{3}{|c|}{ Temperature $\left({ }^{\circ} \mathrm{C}\right)$} & \multirow[b]{2}{*}{90} & \multirow[b]{2}{*}{100} \\
\hline & 60 & 70 & 80 & & \\
\hline \multirow{2}{*}{ Cholesterol } & 0.32 & 0.35 & 0.37 & 0.35 & 0.38 \\
\hline & $(0.01)$ & $(0.03)$ & $(0.01)$ & $(0.02)$ & $(0.02)$ \\
\hline \multirow{2}{*}{ 24- methylene-cholesterol } & 0.13 & 0.14 & 0.13 & 0.14 & 0.14 \\
\hline & $(0.01)$ & $(0.01)$ & $(0.01)$ & $(0.01)$ & $(0.09)$ \\
\hline \multirow[t]{2}{*}{ Campesterol } & 3.35 & 3.38 & 3.33 & 3.36 & 3.39 \\
\hline & $(0.77)$ & $(0.77)$ & $(0.33)$ & $(0.37)$ & $(0.76)$ \\
\hline \multirow[t]{2}{*}{ Campestanol } & 0.17 & 0.18 & 0.17 & 0.17 & 0.17 \\
\hline & $(0.02)$ & $(0.02)$ & $(0.01)$ & $(0.01)$ & $(0.02)$ \\
\hline \multirow[t]{2}{*}{ Stigmasterol } & 1.12 & 1.14 & 1.14 & 1.11 & 1.13 \\
\hline & $(0.15)$ & $(0.16)$ & $(0.15)$ & $(0.15)$ & $(0.15)$ \\
\hline \multirow[t]{2}{*}{ Chlerosterol } & 0.94 & 1.02 & 0.98 & 1.00 & 1.02 \\
\hline & $(0.41)$ & $(0.43)$ & $(0.43)$ & (0.49) & $(0.43)$ \\
\hline \multirow[t]{2}{*}{$\beta$-sitosterol } & 84.42 & 84.27 & 84.31 & 84.21 & 84.37 \\
\hline & $(5.33)$ & (5.30) & $(5.41)$ & (5.43) & (5.37) \\
\hline \multirow[t]{2}{*}{ Sitostanol } & 1.03 & 1.00 & 1.06 & 1.04 & 1.06 \\
\hline & $(0.01)$ & $(0.02)$ & $(0.01)$ & $(0.02)$ & $(0.02)$ \\
\hline \multirow[t]{2}{*}{$\Delta$-5-avenasterol } & 6.49 & 6.47 & 6.43 & 6.52 & 6.50 \\
\hline & $(0.56)$ & $(0.50)$ & $(0.55)$ & $(0.66)$ & (0.68) \\
\hline$\Delta$-5,24-stigmastadienol & 0.77 & 0.79 & 0.78 & 0.78 & 0.75 \\
\hline
\end{tabular}




\begin{tabular}{clllll}
\hline & $(0.04)$ & $(0.04)$ & $(0.04)$ & $(0.02)$ & $(0.04)$ \\
\hline$\Delta$-7-stigmastenol & 0.54 & 0.57 & 0.60 & 0.62 & 0.56 \\
& $(0.08)$ & $(0.08)$ & $(0.07)$ & $(0.08)$ & $(0.08)$ \\
\hline$\Delta$-7- Avenasterol & 0.72 & 0.69 & 0.70 & 0.70 & 0.73 \\
& $(0.21)$ & $(0.22)$ & $(0.31)$ & $(0.27)$ & $(0.11)$ \\
\hline Total Sterols (ppm) & 3675 & 3586 & 3656 & 3655 & 3678
\end{tabular}

a Data are means of triplicates, and SD (standard deviation) is given in parentheses.

Table 5. Sterol composition of pomace-olive oils extracted by the classic or continuous chain

\begin{tabular}{|c|c|c|}
\hline Sterol & $\begin{array}{l}\text { Olive-Pomace Oil } \\
\text { (classic chain) }\end{array}$ & $\begin{array}{l}\text { Olive-Pomace Oil } \\
\text { (continuous chain) }\end{array}$ \\
\hline Cholesterol & $\begin{array}{l}0.21 \\
(0.01)\end{array}$ & $\begin{array}{l}0.19 \\
(0.01)\end{array}$ \\
\hline 24-methylene-cholesterol & $\begin{array}{l}0.20 \\
(0.01)\end{array}$ & $\begin{array}{l}0.16 \\
(0.02)\end{array}$ \\
\hline Campesterol & $\begin{array}{l}3.14 \\
(0.85)\end{array}$ & $\begin{array}{l}3.39 \\
(1.03)\end{array}$ \\
\hline Campestanol & $\begin{array}{l}0.14 \\
(0.01)\end{array}$ & $\begin{array}{l}0.12 \\
(0.01)\end{array}$ \\
\hline Stigmasterol & $\begin{array}{l}1.17 \\
(0.06)\end{array}$ & $\begin{array}{l}1.09 \\
(0.13)\end{array}$ \\
\hline Clerosterol & $\begin{array}{l}0.98 \\
(0.45)\end{array}$ & $\begin{array}{l}0.87 \\
(0.42)\end{array}$ \\
\hline$\beta$-sitosterol & $\begin{array}{l}85.51 \\
(5.35)\end{array}$ & $\begin{array}{l}85.35 \\
(5.32)\end{array}$ \\
\hline Sitostanol & $\begin{array}{l}0.90 \\
(0.08)\end{array}$ & $\begin{array}{l}0.81 \\
(0.07)\end{array}$ \\
\hline$\Delta$-5-avenasterol & $\begin{array}{l}6.04 \\
(0.71)\end{array}$ & $\begin{array}{l}6.21 \\
(0.65)\end{array}$ \\
\hline$\Delta-5,24$-stigmastadienol & 0.62 & 0.54 \\
\hline & $(0.04)$ & $(0.04)$ \\
\hline$\Delta$-7-stigmastenol & $\begin{array}{l}0.53 \\
(0.08)\end{array}$ & $\begin{array}{l}0.67 \\
(0.08)\end{array}$ \\
\hline$\Delta$-7-Avenasterol & $\begin{array}{l}0.56 \\
(0.14)\end{array}$ & $\begin{array}{l}0.60 \\
(0.11)\end{array}$ \\
\hline $\begin{array}{l}\text { Total Sterols } \\
\text { (ppm) }\end{array}$ & 2735 & 3892 \\
\hline
\end{tabular}

a Data are means of triplicates, and SD (standard deviation) is given in parentheses. 
Table 6. Sterol composition of pomace-olive oil extracted in the industrial scale

\begin{tabular}{|c|c|c|c|c|}
\hline Sterol & $\begin{array}{l}100 \% \\
\text { continuous } \\
\text { chain }\end{array}$ & $\begin{array}{l}100 \% \\
\text { classic } \\
\text { chain }\end{array}$ & $\begin{array}{l}80 \% \text { classic chain } \\
+20 \% \text { continuous } \\
\text { chain }\end{array}$ & $\begin{array}{l}40 \% \text { classic chain } \\
+60 \% \text { continuous } \\
\text { chain }\end{array}$ \\
\hline \multirow[t]{2}{*}{ Cholesterol } & 0.19 & 0.21 & 0.23 & 0.20 \\
\hline & $(0.01)$ & $(0.01)$ & $(0.05)$ & $(0.01)$ \\
\hline \multirow{2}{*}{$\begin{array}{l}\text { 24- methylene- } \\
\text { cholesterol }\end{array}$} & 0.16 & 0.20 & 0.17 & 0.21 \\
\hline & $(0.02)$ & $(0.01)$ & $(0.01)$ & $(0.01)$ \\
\hline \multirow[t]{2}{*}{ Campesterol } & 3.39 & 3.14 & 3.29 & 3.30 \\
\hline & (1.03) & $(0.85)$ & $(0.84)$ & $(0.84)$ \\
\hline \multirow[t]{2}{*}{ Campestanol } & 0.12 & 0.14 & 0.13 & 0.15 \\
\hline & $(0.01)$ & $(0.01)$ & $(0.01)$ & $(0.01)$ \\
\hline \multirow[t]{2}{*}{ Stigmasterol } & 1.09 & 1.17 & 1.13 & 1.15 \\
\hline & $(0.13)$ & $(0.06)$ & $(0.12)$ & $(0.13)$ \\
\hline \multirow[t]{2}{*}{ Chlerosterol } & 0.87 & 0.98 & 1.00 & 0.93 \\
\hline & $(0.42)$ & $(0.45)$ & $(0.42)$ & $(0.40)$ \\
\hline \multirow[t]{2}{*}{$\beta$-sitosterol } & 85.35 & 85.51 & 85.28 & 85.17 \\
\hline & (5.32) & (5.35) & $(5.43)$ & (5.33) \\
\hline \multirow[t]{2}{*}{ Sitostanol } & 0.81 & 0.90 & 0.87 & 0.87 \\
\hline & $(0.07)$ & $(0.08)$ & $(0.08)$ & $(0.08)$ \\
\hline \multirow[t]{2}{*}{$\Delta$-5-venasterol } & 6.21 & 6.04 & 6.17 & 6.12 \\
\hline & $(0.65)$ & $(0.71)$ & $(0.70)$ & $(0.66)$ \\
\hline \multirow{2}{*}{$\begin{array}{l}\Delta-5,24- \\
\text { stigmastadienol }\end{array}$} & 0.54 & 0.62 & 0.59 & 0.60 \\
\hline & $(0.04)$ & $(0.04)$ & $(0.07)$ & $(0.04)$ \\
\hline \multirow{2}{*}{$\begin{array}{l}\Delta-7- \\
\text { stigmastenol }\end{array}$} & 0.67 & 0.53 & 0.58 & 0.64 \\
\hline & $(0.08)$ & $(0.08)$ & $(0.08)$ & $(0.08)$ \\
\hline \multirow[t]{2}{*}{$\Delta$-7-venasterol } & 0.60 & 0.56 & 0.56 & 0.61 \\
\hline & $(0.11)$ & $(0.14)$ & $(0.10)$ & $(0.11)$ \\
\hline $\begin{array}{ll}\text { Total } & \text { Sterols } \\
(\mathrm{ppm}) & \end{array}$ & 3892 & 2735 & 2756 & 3292 \\
\hline
\end{tabular}

a Data are means of triplicates, and SD (standard deviation) is given in parentheses. 
Table 7. Sterol composition ${ }^{\mathrm{a}}$ of the pomace-olive oil during the stages of refining

\begin{tabular}{|c|c|c|c|c|c|}
\hline Sterol & $\begin{array}{l}\text { POO } \\
\text { raw }\end{array}$ & $\begin{array}{l}\text { Decired } \\
\text { POO }\end{array}$ & $\begin{array}{l}\text { Neutralized } \\
\text { POO }\end{array}$ & $\begin{array}{l}\text { Bleached } \\
\text { POO }\end{array}$ & $\begin{array}{l}\text { Deodorized } \\
\text { POO }\end{array}$ \\
\hline \multirow[t]{2}{*}{ Cholesterol } & 0.32 & 0.34 & 0.35 & 0.33 & 0.34 \\
\hline & $(0.01)$ & $(0.01)$ & $(0.01)$ & $(0.03)$ & $(0.01)$ \\
\hline \multirow{2}{*}{$\begin{array}{l}\text { 24- methylene- } \\
\text { cholesterol }\end{array}$} & 0.13 & 0.12 & 0.12 & 0.12 & 0.11 \\
\hline & $(0.02)$ & $(0.01)$ & $(0.01)$ & $(0.01)$ & $(0.11)$ \\
\hline \multirow[t]{2}{*}{ Campesterol } & 3.35 & 3.28 & 3.29 & 3.27 & 3.30 \\
\hline & $(0.83)$ & $(0.87)$ & $(0.83)$ & $(1.02)$ & $(0.83)$ \\
\hline \multirow[t]{2}{*}{ Campestanol } & 0.17 & 0.17 & 0.17 & 0.17 & 0.19 \\
\hline & $(0.04)$ & $(0.01)$ & $(0.01)$ & $(0.01)$ & $(0.01)$ \\
\hline \multirow[t]{2}{*}{ Stigmasterol } & 1.12 & 1.17 & 1.18 & 1.17 & 1.19 \\
\hline & $(0.17)$ & $(0.16)$ & $(0.13)$ & $(0.16)$ & $(0.16)$ \\
\hline \multirow[t]{2}{*}{ Chlerosterol } & 0.94 & 0.94 & 0.94 & 0.95 & 0.96 \\
\hline & $(0.49)$ & $(0.49)$ & $(0.48)$ & $(0.49)$ & $(0.55)$ \\
\hline \multirow[t]{2}{*}{$\beta$-sitosterol } & 84.82 & 84.79 & 84.61 & 84.54 & 84.53 \\
\hline & $(5.55)$ & $(5.55)$ & $(5.54)$ & $(5.55)$ & $(5.60)$ \\
\hline \multirow[t]{2}{*}{ Sitostanol } & 1.03 & 1.03 & 1.02 & 1.04 & 1.02 \\
\hline & $(0.02)$ & $(0.02)$ & $(0.02)$ & $(0.08)$ & $(0.12)$ \\
\hline \multirow{2}{*}{$\begin{array}{l}\Delta-5- \\
\text { avenasterol }\end{array}$} & 6.09 & 6.13 & 6.10 & 6.11 & 6.11 \\
\hline & $(0.71)$ & $(0.90)$ & $(0.71)$ & $(0.71)$ & $(0.81)$ \\
\hline \multirow{2}{*}{$\begin{array}{l}\Delta-5,24- \\
\text { stigmastadienol }\end{array}$} & 0.77 & 0.78 & 0.77 & 0.79 & 0.78 \\
\hline & $(0.02)$ & & $(0.02)$ & $(0.02)$ & $(0.02)$ \\
\hline \multirow{2}{*}{$\begin{array}{l}\Delta-7- \\
\text { stigmastenol }\end{array}$} & 0.54 & 0.56 & 0.72 & 0.78 & 0.79 \\
\hline & $(0.08)$ & $(0.07)$ & $(0.08)$ & $(0.08)$ & $(0.08)$ \\
\hline \multirow{2}{*}{${ }_{\text {Avenasterol }}^{-7-}$} & 0.72 & 0.69 & 0.68 & 0.73 & 0.68 \\
\hline & $(0.15)$ & $(0.16)$ & $(0.15)$ & $(0.15)$ & \\
\hline $\begin{array}{l}\text { Total } \\
\text { (ppm) }\end{array}$ & 3675 & - & 2786 & 2510 & 1994 \\
\hline
\end{tabular}

a Data are means of triplicates, and SD (standard deviation) is given in parentheses. 
Table 8. Sterol composition ${ }^{a}$ of Tunisian, Spanich and Portugais pomace-olive oils before and after refining

\begin{tabular}{|c|c|c|c|c|c|c|}
\hline \multirow[t]{2}{*}{ Sterol } & \multicolumn{2}{|c|}{ Tunisian variety } & \multicolumn{2}{|c|}{ Spanich variety } & \multicolumn{2}{|c|}{ Portugais variety } \\
\hline & $\begin{array}{l}\mathrm{POO} \\
\text { raw }\end{array}$ & $\begin{array}{l}\text { Refined } \\
\text { POO }\end{array}$ & $\begin{array}{l}\mathrm{POO} \\
\text { raw }\end{array}$ & $\begin{array}{l}\text { Refined } \\
\text { POO }\end{array}$ & $\begin{array}{l}\text { POO } \\
\text { raw }\end{array}$ & $\begin{array}{l}\text { Refined } \\
\text { POO }\end{array}$ \\
\hline \multirow[t]{2}{*}{ Cholesterol } & 0.32 & 0.34 & 0.14 & 0.20 & 0.06 & 0.12 \\
\hline & $(0.04)$ & $(0.04)$ & $(0.02)$ & $(0.02)$ & $(0.02)$ & $(0.02)$ \\
\hline \multirow{2}{*}{$\begin{array}{l}\text { 24-methylene- } \\
\text { cholesterol }\end{array}$} & 0.13 & 0.11 & 0.06 & 0.08 & 0.10 & 0.09 \\
\hline & $(0.01)$ & $(0.02)$ & $(0.01)$ & $(0.01)$ & $(0.01)$ & $(0.01)$ \\
\hline \multirow[t]{2}{*}{ Campesterol } & 3.35 & 3.30 & 3.42 & 3.51 & 3.04 & 3.19 \\
\hline & $(0.70)$ & $(0.80)$ & $(0.80)$ & $(0.81)$ & $(0.81)$ & $(0.81)$ \\
\hline \multirow[t]{2}{*}{ Campestanol } & 0.17 & 0.19 & 0.14 & 0.15 & 0.16 & 0.13 \\
\hline & $(0.01)$ & $(0.01)$ & $(0.01)$ & $(0.01)$ & $(0.01)$ & $(0.01)$ \\
\hline \multirow[t]{2}{*}{ Stigmasterol } & 1.12 & 1.19 & 1.14 & 1.19 & 1.21 & 1.30 \\
\hline & $(0.15)$ & $(0.08)$ & $(0.14)$ & $(0.14)$ & $(0.13)$ & $(0.14)$ \\
\hline \multirow[t]{2}{*}{ Chlerosterol } & 0.94 & 0.96 & 1.11 & 1.07 & 1.07 & 1.16 \\
\hline & $(0.37)$ & $(0.40)$ & $(0.37)$ & $(0.37)$ & $(0.39)$ & $(0.40)$ \\
\hline \multirow[t]{2}{*}{$\beta$-sitosterol } & 84.82 & 84.53 & 86.93 & 86.52 & 87.68 & 87.06 \\
\hline & $(5.45)$ & $(5.45)$ & $(5.45)$ & $(5.45)$ & (5.35) & $(5.45)$ \\
\hline \multirow[t]{2}{*}{ Sitostanol } & 1.03 & 1.02 & 2.03 & 1.99 & 2.06 & 2.06 \\
\hline & $(0.11)$ & $(0.10)$ & $(0.09)$ & $(0.11)$ & $(0.11)$ & $(0.11)$ \\
\hline \multirow[t]{2}{*}{$\Delta$-5-avenasterol } & 6.09 & 6.12 & 1.38 & 1.44 & 1.33 & 1.42 \\
\hline & $(0.81)$ & $(0.81)$ & $(0.54)$ & $(0.81)$ & $(0.81)$ & $(0.80)$ \\
\hline \multirow{2}{*}{$\begin{array}{l}\Delta-5,24- \\
\text { stigmastadienol }\end{array}$} & 0.77 & 0.78 & 1.87 & 1.79 & 1.82 & 1.73 \\
\hline & $(0.07)$ & $(0.07)$ & $(0.02)$ & $(0.07)$ & $(0.07)$ & $(0.05)$ \\
\hline \multirow[t]{2}{*}{$\Delta$-7-stigmastenol } & 0.54 & 0.79 & 0.24 & 0.40 & 0.30 & 0.42 \\
\hline & $(0.07)$ & $(0.08)$ & $(0.08)$ & $(0.08)$ & $(0.08)$ & $(0.08)$ \\
\hline \multirow[t]{2}{*}{$\Delta$-7- Avenasterol } & 0.72 & 0.68 & 1.54 & 1.66 & 1.17 & 1.32 \\
\hline & $(0.32)$ & $(0.32)$ & $(0.32)$ & $(0.30)$ & $(0.44)$ & $(0.32)$ \\
\hline
\end{tabular}

a Data are means of triplicates, and SD (standard deviation) is given in parentheses. 
Table 9. Sterol composition ${ }^{a}$ of pomace-olive oil neutralized by soda or by lime

\begin{tabular}{|c|c|c|c|c|c|c|}
\hline Sterol & $\begin{array}{l}{ }^{\mathrm{D}} \mathrm{POO} \\
\text { raw }\end{array}$ & $\begin{array}{l}{ }^{\mathrm{D}} \mathrm{POO} \\
\text { neutralized } \\
\text { by soda }\end{array}$ & $\begin{array}{l}{ }^{\mathrm{D}} \mathrm{POO} \\
\text { neutralized } \\
\text { by lime }\end{array}$ & $\begin{array}{l}{ }^{\mathrm{c}} \mathrm{POO} \\
\text { raw }\end{array}$ & $\begin{array}{l}{ }^{c} \mathrm{POO} \\
\text { neutralized } \\
\text { by soda }\end{array}$ & $\begin{array}{l}{ }^{\mathrm{c}} \mathrm{POO} \\
\text { neutralized } \\
\text { by lime }\end{array}$ \\
\hline \multirow[t]{2}{*}{ Cholesterol } & 0.32 & 0.35 & 0.23 & 0.21 & 0.24 & 0.16 \\
\hline & $(0.04)$ & $(0.01)$ & $(0.05)$ & $(0.01)$ & $(0.03)$ & $(0.02)$ \\
\hline \multirow{2}{*}{$\begin{array}{l}\text { 24- methylene- } \\
\text { cholesterol }\end{array}$} & 0.13 & 0.12 & 0.17 & 0.13 & 0.10 & 0.16 \\
\hline & $(0.01)$ & $(0.01)$ & $(0.01)$ & $(0.01)$ & $(0.10)$ & $(0.02)$ \\
\hline \multirow[t]{2}{*}{ Campesterol } & 3.35 & 3.29 & 3.29 & 3.27 & 3.22 & 3.26 \\
\hline & $(1.14)$ & $(0.83)$ & $(0.84)$ & $(0.30)$ & $(0.30)$ & $(0.83)$ \\
\hline \multirow[t]{2}{*}{ Campestanol } & 0.17 & 0.17 & 0.13 & 0.19 & 0.19 & 0.17 \\
\hline & $(0.02)$ & $(0.01)$ & $(0.01)$ & $(0.01)$ & $(0.01)$ & $(0.02)$ \\
\hline \multirow[t]{2}{*}{ Stigmasterol } & 1.12 & 1.18 & 1.13 & 1.19 & 1.21 & 1.13 \\
\hline & $(0.07)$ & $(0.13)$ & $(0.12)$ & $(0.13)$ & $(0.03)$ & $(0.13)$ \\
\hline \multirow[t]{2}{*}{ Clerosterol } & 0.94 & 0.94 & 1.00 & 0.97 & 0.68 & 0.88 \\
\hline & $(0.56)$ & $(0.48)$ & $(0.42)$ & $(0.43)$ & $(0.43)$ & $(0.49)$ \\
\hline \multirow[t]{2}{*}{$\beta$-sitosterol } & 84.42 & 84.61 & 85.28 & 85.64 & 84.39 & 85.22 \\
\hline & $(5.45)$ & $(5.54)$ & $(5.43)$ & $(5.40)$ & (5.33) & $(5.55)$ \\
\hline \multirow[t]{2}{*}{ Sitostanol } & 1.03 & 1.02 & 0.87 & 0.88 & 1.30 & 1.26 \\
\hline & $(0.01)$ & $(0.02)$ & $(0.08)$ & $(0.02)$ & $(0.08)$ & $(0.08)$ \\
\hline \multirow[t]{2}{*}{$\Delta$-5-avenasterol } & 6.49 & 6.10 & 6.17 & 5.98 & 6.64 & 6.13 \\
\hline & $(0.66)$ & $(0.71)$ & $(0.70)$ & $(0.62)$ & $(0.66)$ & $(0.61)$ \\
\hline \multirow{2}{*}{$\begin{array}{l}\Delta-5,24- \\
\text { stigmastadienol }\end{array}$} & 0.77 & 0.77 & 0.59 & 0.63 & 0.58 & 0.53 \\
\hline & $(0.02)$ & $(0.02)$ & $(0.07)$ & $(0.02)$ & $(0.07)$ & $(0.04)$ \\
\hline \multirow{2}{*}{$\begin{array}{l}\Delta-7- \\
\text { stigmastenol }\end{array}$} & 0.54 & 0.72 & 0.58 & 0.53 & 0.78 & 0.61 \\
\hline & $(0.08)$ & $(0.08)$ & $(0.08)$ & $(0.07)$ & $(0.08)$ & $(0.08)$ \\
\hline \multirow{2}{*}{$\begin{array}{l}\Delta-7- \\
\text { Avenasterol }\end{array}$} & 0.72 & 0.68 & 0.56 & 0.38 & 0.67 & 0.49 \\
\hline & $(0.11)$ & $(0.15)$ & $(0.10)$ & $(0.14)$ & $(0.11)$ & $(0.14)$ \\
\hline
\end{tabular}

a Data are means of triplicates, and SD (standard deviation) is given in parentheses

b First pomace oil sample

c Second pomace oil sample. 